\title{
Improvement of TMI Rain Retrievals in Mountainous Areas
}

\section{$\operatorname{AUTHOR}(\mathrm{S})$ :}

Shige, Shoichi; Kida, Satoshi; Ashiwake, Hiroki; Kubota, Takuji; Aonashi, Kazumasa

\section{CITATION:}

Shige, Shoichi ...[et al]. Improvement of TMI Rain Retrievals in Mountainous Areas. Journal of Applied Meteorology and Climatology 2013, 52(1): 242-254

\section{ISSUE DATE:}

2013-01

URL:

http://hdl.handle.net/2433/177486

RIGHT:

(C) American Meteorological Society 


\title{
Improvement of TMI Rain Retrievals in Mountainous Areas
}

\author{
SHOICHI SHIGE \\ Graduate School of Science, Kyoto University, Kyoto, Japan \\ SATOSHI KIDA \\ Earth Observation Research Center, Japan Aerospace Exploration Agency, Tsukuba, Japan \\ HIROKI ASHIWAKE \\ Graduate School of Engineering, Osaka Prefecture University, Sakai, Japan \\ TAKUJI KUBOTA \\ Earth Observation Research Center, Japan Aerospace Exploration Agency, Tsukuba, Japan \\ KAZUMASA AONASHI \\ Meteorological Research Institute, Japan Meteorological Agency, Tsukuba, Japan
}

(Manuscript received 19 March 2012, in final form 24 August 2012)

\begin{abstract}
Heavy rainfall associated with shallow orographic rainfall systems has been underestimated by passive microwave radiometer algorithms owing to weak ice scattering signatures. The authors improve the performance of estimates made using a passive microwave radiometer algorithm, the Global Satellite Mapping of Precipitation (GSMaP) algorithm, from data obtained by the Tropical Rainfall Measuring Mission (TRMM) Microwave Imager (TMI) for orographic heavy rainfall. An orographic/nonorographic rainfall classification scheme is developed on the basis of orographically forced upward vertical motion and the convergence of surface moisture flux estimated from ancillary data. Lookup tables derived from orographic precipitation profiles are used to estimate rainfall for an orographic rainfall pixel, whereas those derived from original precipitation profiles are used to estimate rainfall for a nonorographic rainfall pixel. Rainfall estimates made using the revised GSMaP algorithm are in better agreement with estimates from data obtained by the radar on the TRMM satellite and by gauge-calibrated ground radars than are estimates made using the original GSMaP algorithm.
\end{abstract}

\section{Introduction}

Observations by microwave radiometers (MWRs) in low Earth orbit and by infrared radiometers (IRs) in geostationary Earth orbit have been combined to improve satellite rainfall estimates on the basis of retaining the strengths of the individual techniques since the work by Adler et al. (1993), who estimated monthly rainfall. With the great success of the Tropical Rainfall Measuring

Corresponding author address: Shoichi Shige, Graduate School of Science, Kyoto University, Kitashirakawa-Oiwake-cho, Sakyoku, Kyoto, 606-8502, Japan.

E-mail: shige@kugi.kyoto-u.ac.jp
Mission (TRMM; Simpson et al. 1996), which carries the first spaceborne precipitation radar (PR) (Kozu et al. 2001; Okamoto 2003), the development of MWR algorithms has accelerated. The improved MWR algorithms and the greater number of MWRs in orbits encourage us to develop high-resolution satellite rainfall products $\left(0.1^{\circ}-0.25^{\circ}\right.$ latitude/longitude and $0.5-3$ hourly) by combining data obtained by MWRs and IRs such as the TRMM Multisatellite Precipitation Analysis (TMPA; Huffman et al. 2007), the Climate Prediction Center Morphing product (CMORPH; Joyce et al. 2004), the Self-Calibrating Multivariate Precipitation Retrieval (SCaMPR; Kuligowski 2002), the Precipitation Estimation from Remotely Sensed Information using Artificial 
Neural Networks (PERSIANN; Sorooshian et al. 2000), the Passive Microwave-Infrared product (PMIR; Kidd et al. 2003), the Naval Research Laboratory-Blended product (NRL; Turk and Miller 2005), and the Global Satellite Mapping of Precipitation product (GSMaP; Ushio et al. 2009). These datasets have been used for flood and landslide analysis/prediction (e.g., Hong et al. 2007). Reviews of satellite rainfall products and their surface hydrologic applications are found in Gebrenuchael and Hossain (2010).

Surface hydrologic applications of satellite rainfall products are still at the experimental stage because of the poor performance of satellite estimates over land, particularly over mountainous areas. Negri and Adler (1993) showed that IR techniques did poorly in estimating the rain maxima in Japan associated with shallow orographic (warm) rain systems (Takeda et al. 1976; Takeda and Takase 1980; Sakakibara 1981). Although brightness temperatures Tb obtained from MWR observations have a more direct relationship with rainfall rates than IR cloud-top Tb, MWR algorithms underestimate rainfall associated with shallow orographic rain systems. Todd and Bailey (1995) showed that an MWR algorithm underestimates rain rates associated with shallow orographic rain systems over upland areas of Wales and northwestern England in the United Kingdom. Kubota et al. (2009) more recently showed poor verification results of the high-resolution satellite rainfall products for mountainous regions over Japan and suggested that one of the main reasons for such error is that MWR algorithms underestimate heavy rainfall associated with shallow orographic rainfall systems. Satellite methods underestimate heavy rainfall associated with shallow orographic rainfall systems because they assume that heavy rainfall results from deep clouds. Some of the rainiest areas around the world, however, such as the west coast of India during the summer monsoon, are dominated by shallow orographic rain systems (Houze 1993; Liu and Zipser 2009).

Efforts have been made to improve the accuracy of satellite estimates over complex-terrain areas where ground-radar and rain gauge measurements are limited. Vicente et al. (2002) developed a topographic correction technique for an IR-based rain retrieval such as the Hydro-Estimator (Scofield and Kuligowski 2003). Kwon et al. (2008) recently developed topographic correction factors for terrain of the Korean Peninsula in the Goddard profiling (GPROF) algorithm (Kummerow et al. 2001; McCollum and Ferraro 2003; Olson et al. 2006; Wang et al. 2009), which is the TRMM Microwave Imager (TMI) facility algorithm, as a function of terrain slope, low-level wind, and moisture parameters.
In this paper, we improve the performance of rainfall estimates made by the GSMaP algorithm from TMI data (Aonashi et al. 2009; Kubota et al. 2007) for the Kii Peninsula, which is a heavy-rainfall region in Japan for which satellite methods of estimating the rain maximum have been shown to be poor (Negri and Adler 1993; Kubota et al. 2009). Following the study of Kwon et al. (2008), we use parameters of terrain slope, low-level wind, and moisture. We introduce not topographical correction factors to the GSMaP algorithm, however, but rather the dynamic selection of lookup tables (LUTs) that are appropriate for orographic heavy rainfall, and we estimate rainfall rates from observed $\mathrm{Tb}$ using the LUTs.

\section{Data}

In this paper, we use the data obtained by the PR and TMI on board the TRMM satellite. The PR, an active microwave sensor, provides height information that is based on the time delay of the precipitation-backscattered return power and allows vertical profiles of precipitation to be obtained directly over the global tropics. The TMI, a passive microwave sensor, measures radiances that are the end product of the integrated effects of electromagnetic absorption/emission and scattering through a precipitating cloud along the sensor view path. Although the PR algorithm has weaknesses such as assumptions about the raindrop size distribution (Iguchi et al. 2000, 2009; Shige et al. 2008), rainfall retrievals using data from the PR are in principle superior to those using data from the TMI, particularly over land. The lower contrast between the surface and atmosphere due to high and variable emissivity over land makes it difficult to use an emission signature from raindrops over the spectrum of lower frequencies of the TMI; hence, a scattering signature from ice crystals over the spectrum of higher frequencies is mainly used. Thus, a comparison of TMI estimates with PR estimates is useful for the improvement and validation of TMI rainfall retrievals.

The GSMaP algorithm consists of a forward-calculation part to calculate LUTs showing the relationship between the rainfall rate and $\mathrm{Tb}$ with a radiative transfer model (RTM) and a retrieval part to estimate the precipitation rate from the observed Tb using the LUTs. Here, the GSMaP overland algorithm is described. For details, refer to Aonashi et al. (2009).

From forward calculations with a four-stream RTM (Liu 1998), LUTs showing the relationship between the rainfall rate and $\mathrm{Tb}$ were computed daily in $5.0^{\circ} \times$ $5.0^{\circ}$ latitude-longitude boxes. The RTM calculation requires information on atmospheric variables and 
(a) PR nearSurfRain

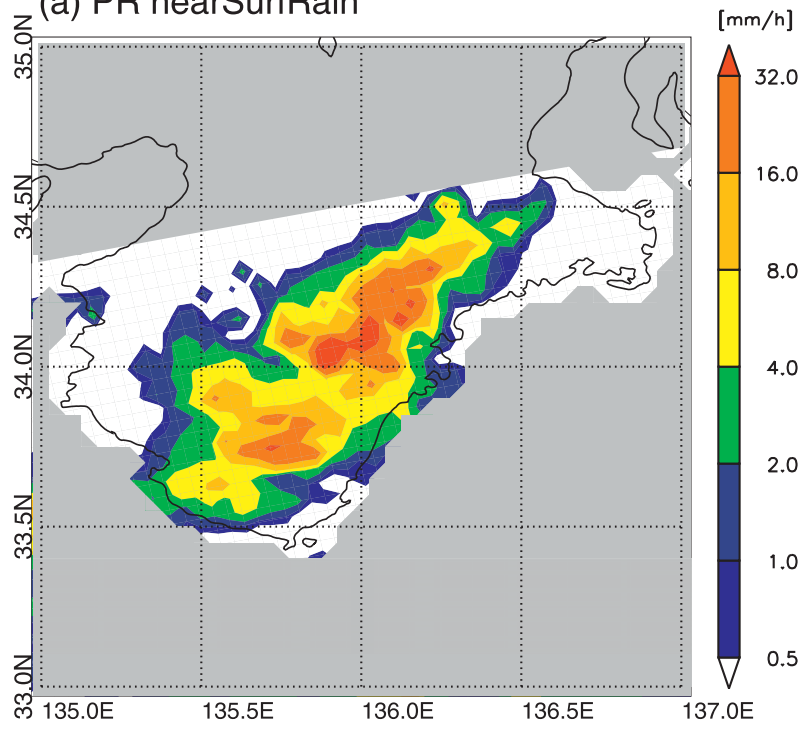

(c) GSMaP1

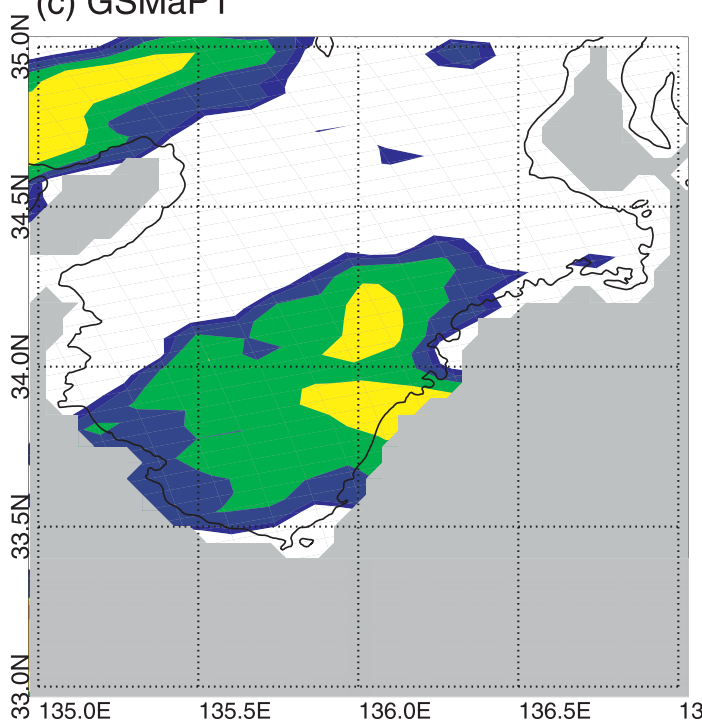

$[\mathrm{mm} / \mathrm{h}]$

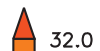

(b) TMI PCT85

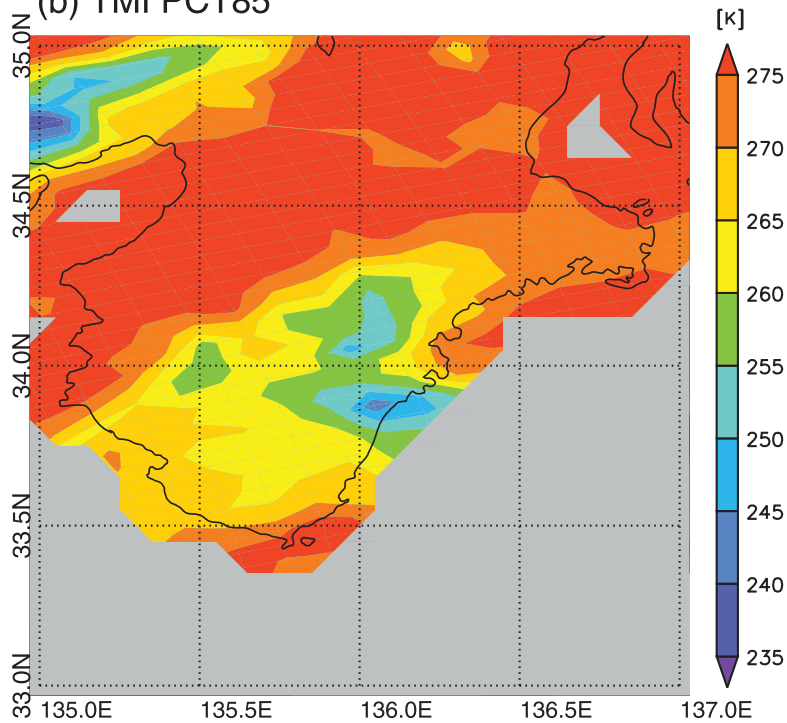

(d) GTOPO30

\section{}

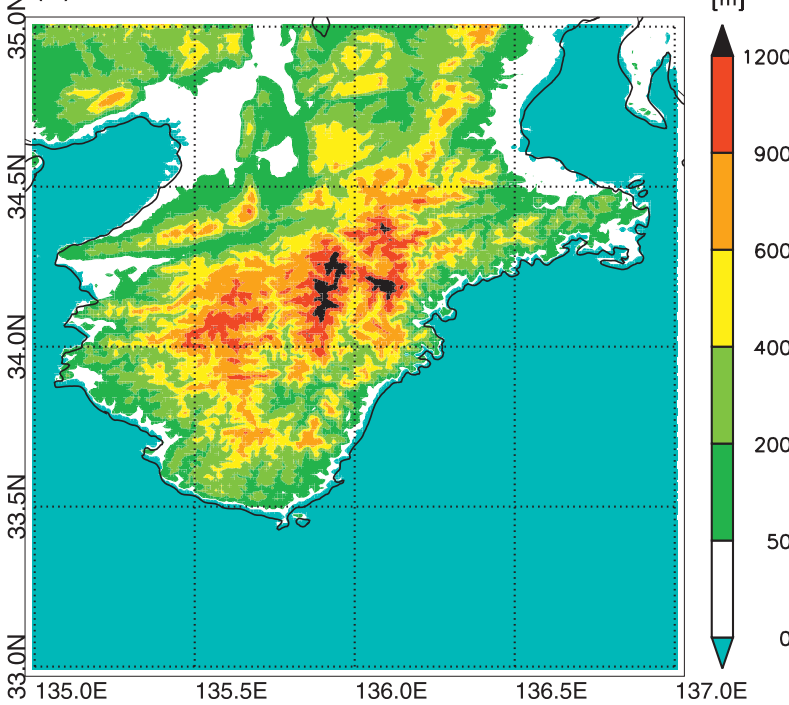

FIG. 1. Case study of orographic rainfall over the Kii Peninsula on 30 Jul 2004 (TRMM orbit No. 38228): (a) PR 2A25 near-surface rain rate $\left(\mathrm{mm} \mathrm{h}^{-1}\right)$, (b) TMI PCT85 (K), (c) GSMaP1 surface rain $\left(\mathrm{mm} \mathrm{h}^{-1}\right)$, and (d) GTOPO30 elevation (m). The observation times of PR and TMI data were 1534 and 1533 UTC, respectively.

precipitation-related variables. In this study, atmospheric temperature, freezing-level height (FLH), and surface temperature are adapted from the Japanese 25-year Reanalysis (JRA-25) (Onogi et al. 2007), which was completed using the Japan Meteorological Agency (JMA) numerical assimilation and forecast system and has been continued as the JMA Climate Data Assimilation System (JCDAS).

The convective and stratiform precipitation models for precipitation-related variables such as hydrometers profiles are constructed for seven land precipitation types. Precipitation types are determined in terms of the stratiform pixel ratio, stratiform rain ratio, precipitation area, precipitation-top height, rain intensity, and diurnal cycle obtained from the PR data, together with the ratio between PR precipitation rates and TRMM Lightning Imaging Sensor flash rates (Takayabu 2006, 2008). Global distributions of the precipitation types in $2.5^{\circ} \times$ $2.5^{\circ}$ latitude-longitude boxes are statistically classified trimonthly. The convective and stratiform precipitation profiles of PR data are averaged over prescribed precipitation ranges for each precipitation type. In this averaging, profiles relative to the FLH are used to exclude the effect of atmospheric temperature variations. The database of precipitation types and profiles makes it 
(a)

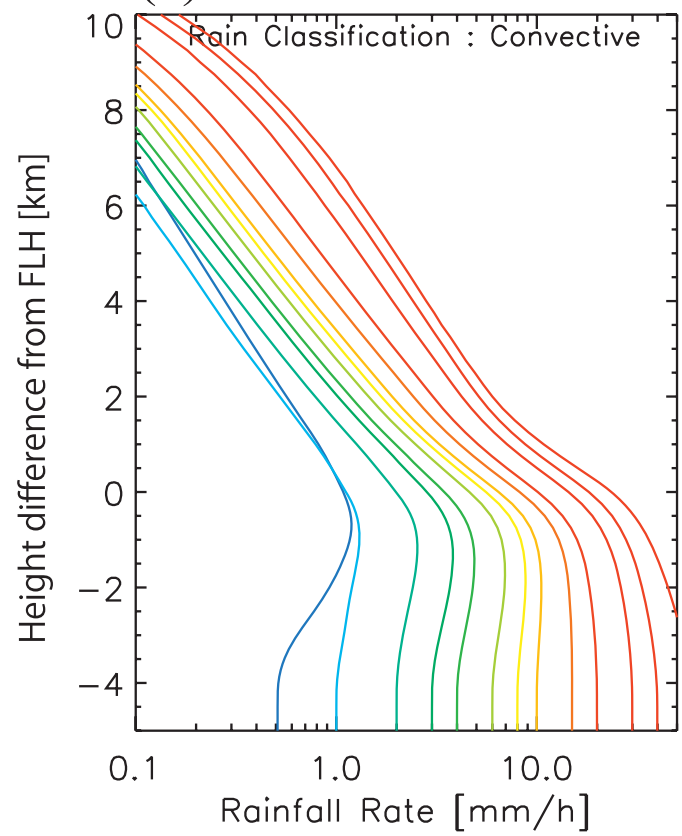

(c)

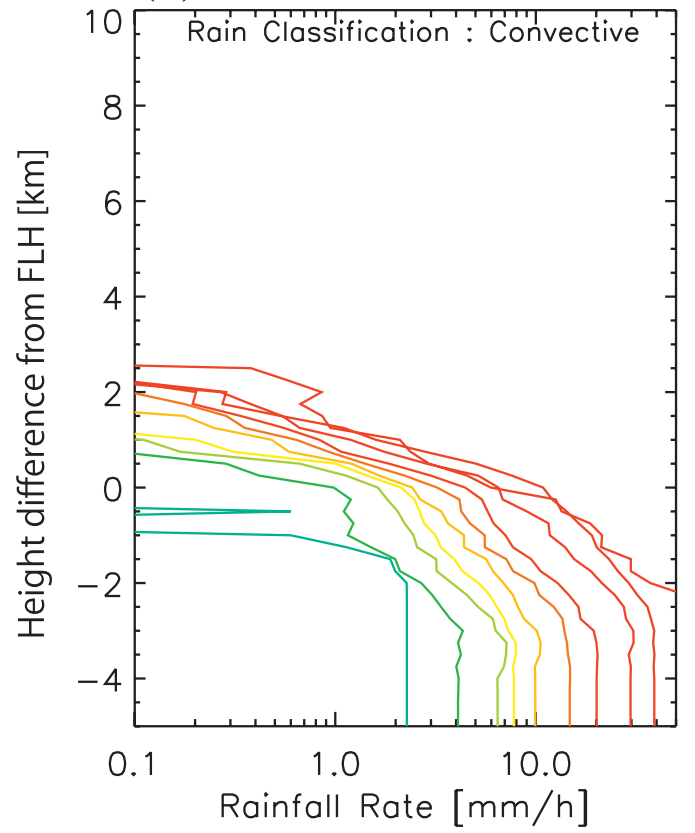

(b)

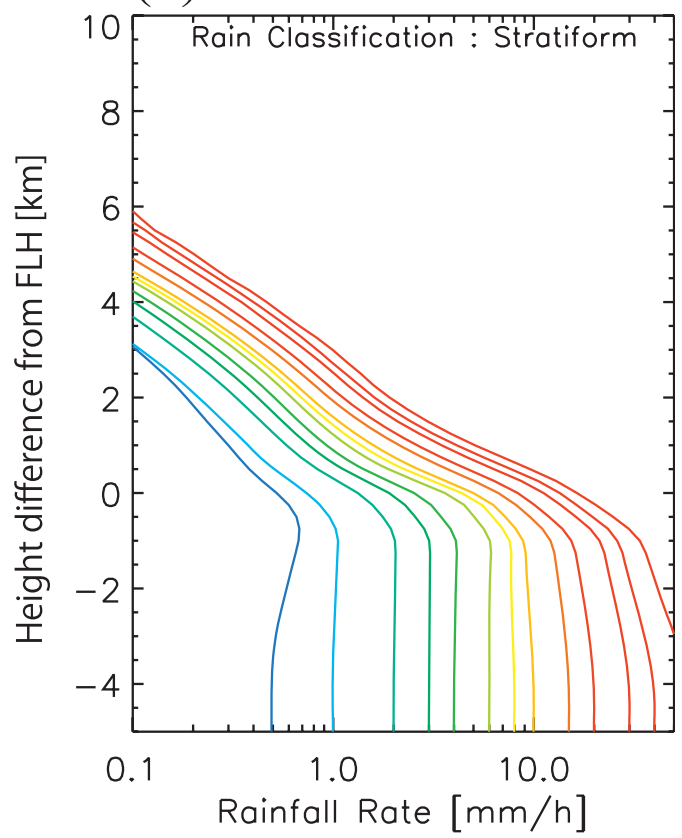

(d)

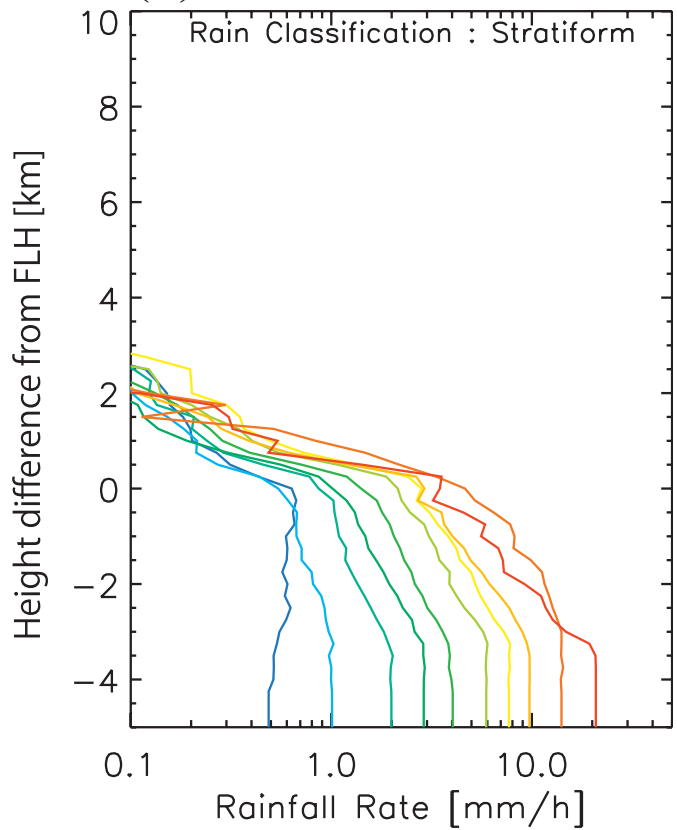

FIG. 2. Precipitation profile models for (a) convective and (b) stratiform rainfall rain used by the GSMaP1 algorithm to produce a LUT for rain retrieval in the case shown in Fig. 1c; (c) convective and (d) stratiform rainfall rain obtained by averaging the convective and stratiform precipitation profiles observed by the PR for the case shown in Fig. 1a. The ordinate is the height difference from the FLH.

possible for the algorithm to deal with trimonthly variation in typical hydrometeor profiles.

The rain/no-rain classification method of Seto et al. (2005) was used over land, and that of Kubota et al.
(2007), which is an improvement of the McCollum and Ferraro (2005) method, was used over coasts. The surface rainfall estimate is obtained by combining estimates from the polarization-corrected temperatures (Spencer 


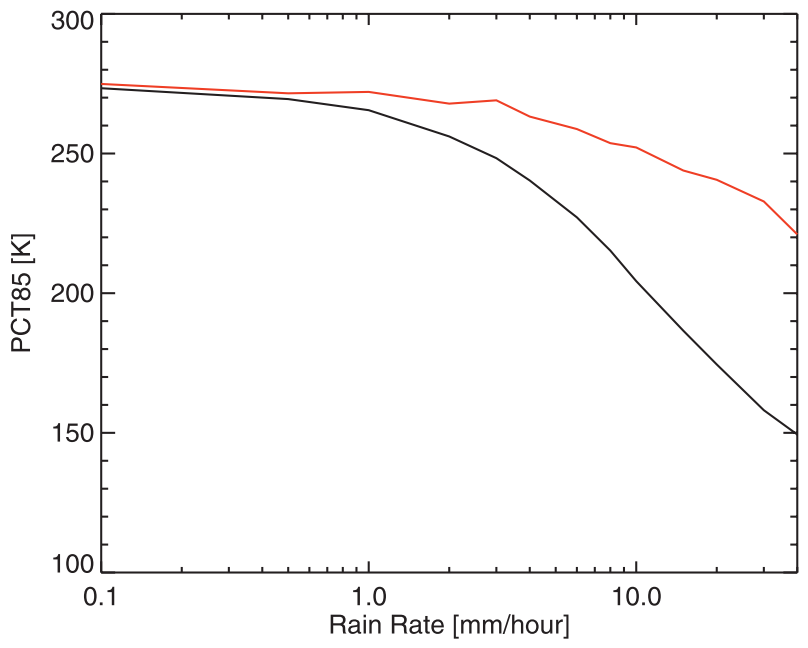

FIG. 3. LUTs for PCT85 calculated from precipitation profiles shown in Figs. 2a and 2b (black line) and those shown in Figs. 2c and $2 \mathrm{~d}$ (red line).

et al. 1989) at $85 \mathrm{GHz}(\mathrm{PCT} 85)$ and $37 \mathrm{GHz}$ (PCT37) using LUTs.

The Radar-Automated Meteorological Data Acquisition System (AMeDAS) precipitation analysis (hereinafter RA; Makihara et al. 1996; Makihara 2007) for 2004 is used to validate the GSMaP estimates. The RA data are a 1-h accumulated-precipitation estimate created from a composite of JMA operational 10-min-cycle radar data, calibrated by rain gauges of the AMeDAS network. Spatial and temporal resolutions of the RA have been upgraded by the JMA. For the period between June 2003 and December 2005, the spatial resolution was $0.025^{\circ}$ latitude and $0.03125^{\circ}$ longitude (about $2.5 \mathrm{~km} \times 2.5 \mathrm{~km}$ ) and the temporal resolution was $30 \mathrm{~min}$. The RA data have been used by Negri and Adler (1993), and Kubota et al. $(2007,2009)$ to validate satellite rainfall products and at the International Precipitation Working Group regional validation site in Japan (Kidd et al. 2010).

\section{Algorithm improvements}

\section{a. Case studies}

Figure 1 presents a case of orographic rainfall over the Kii Peninsula on 30 July 2004, associated with Typhoon Namtheun, which was examined by Kubota et al. (2009). High surface rain rates of $>25 \mathrm{~mm} \mathrm{~h}^{-1}$ were detected around Owase $\left(34^{\circ} \mathrm{N}, 136^{\circ} \mathrm{E}\right)$, where mountains higher than $500 \mathrm{~m}$ are very close to the coastline running northeast to southwest (Fig. 1d), in version 6 of the PR data (Fig. 1a) and in the RA data (Kubota et al. 2009, their Fig. 15a). Large surface rainfall events, such as those seen in radar observations, were not detected in the surface rain data retrieved from TMI data by the original GSMaP algorithm (hereinafter GSMaP1; Fig. 1c) or by version 6 of the GPROF algorithm (Kubota et al. 2009, their Fig. 15d). In both algorithms, surface rain rates over land are computed mainly according to observed PCT85 (Fig. 1b).

Figure 2 shows the convective and stratiform precipitation profiles used by the GSMaP1 algorithm for the case shown in Fig. 1. For all prescribed precipitation ranges, precipitation-top heights reach $6 \mathrm{~km}$ above the FLH for convective rain and $3 \mathrm{~km}$ above the FLH for stratiform rain, which is a manifestation of active coldrain processes, and are representative of rain over land. The convective and stratiform precipitation profiles obtained from the data for the case of orographic rainfall are shown in Figs. $2 \mathrm{c}$ and $2 \mathrm{~d}$. Throughout the prescribed precipitation range, precipitation-top heights do not reach $3 \mathrm{~km}$ above the FLH for either convective or stratiform rain, demonstrating weaker cold-rain processes and being remarkably different from the precipitation profiles used by the GSMaP1 algorithm shown in Figs. 2a and 2b. Heavy rainfall from shallow clouds in this area has been reported by previous studies (Takeda et al. 1976; Takeda and Takase 1980; Sakakibara 1981).

Figure 3 shows the PCT 85 dependence on the surface rain rate (i.e., LUTs) calculated using original precipitation profiles (Figs. 2a,b) and orographic precipitation profiles (Figs. 2c,d). The GSMaP algorithm uses not only PCT85 but also PCT37 to reduce the overestimation of rainfall from scattering signatures associated with tall precipitation where the thickness of the ice layer between the precipitation-top height and the FLH is greater than $4 \mathrm{~km}$ (Aonashi et al. 2009). In this case, the scattering signatures are not strong, and the GSMaP algorithm therefore mainly uses PCT85. It is seen that PCT85 calculated from the original precipitation profiles decreases more rapidly with the rainfall rate than that calculated from orographic precipitation profiles, because the thickness of the ice layer in the original precipitation profiles is greater than that in the orographic precipitation profiles. Therefore, for a given PCT85 (e.g., $250 \mathrm{~K}$ ), the LUT obtained from the original precipitation profiles gives a rain rate (e.g., $3 \mathrm{~mm} \mathrm{~h}^{-1}$ ) that is lower than that obtained from orographic precipitation profiles (e.g., $10 \mathrm{~mm} \mathrm{~h}^{-1}$ ), leading to underestimation by the GSMaP1 algorithm.

Figure 4 presents a case of orographic rainfall over the Kii Peninsula on 30 March 2004 that is associated with a frontal cyclone. In this case, the PR algorithm estimates heavy rainfall on the southeast coast (Fig. 4a), which is in agreement with the RA data (not shown). Also for this case, the surface rain rates estimated by the 
(a) PR nearSurfRain

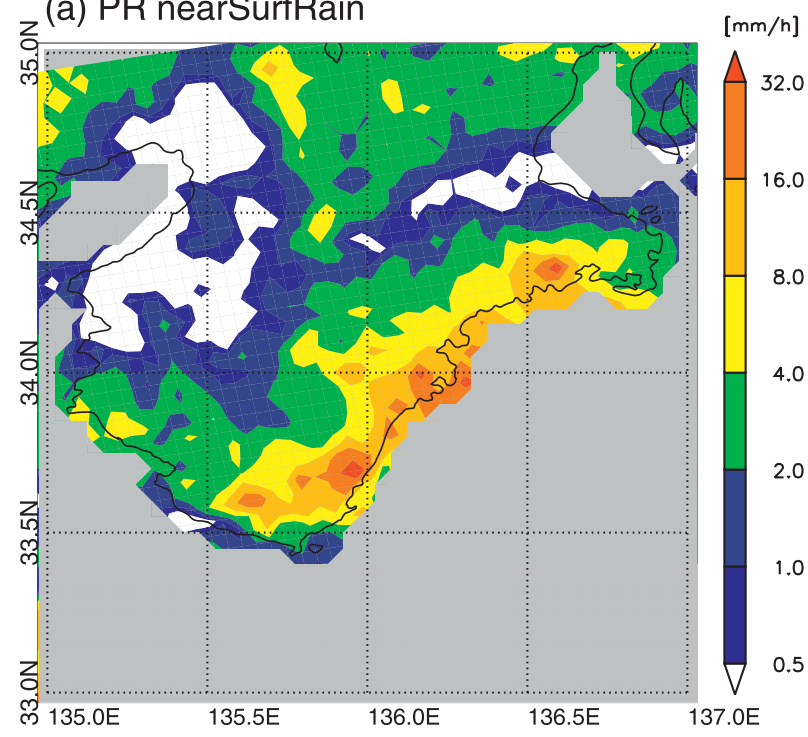

(c) GSMaP1

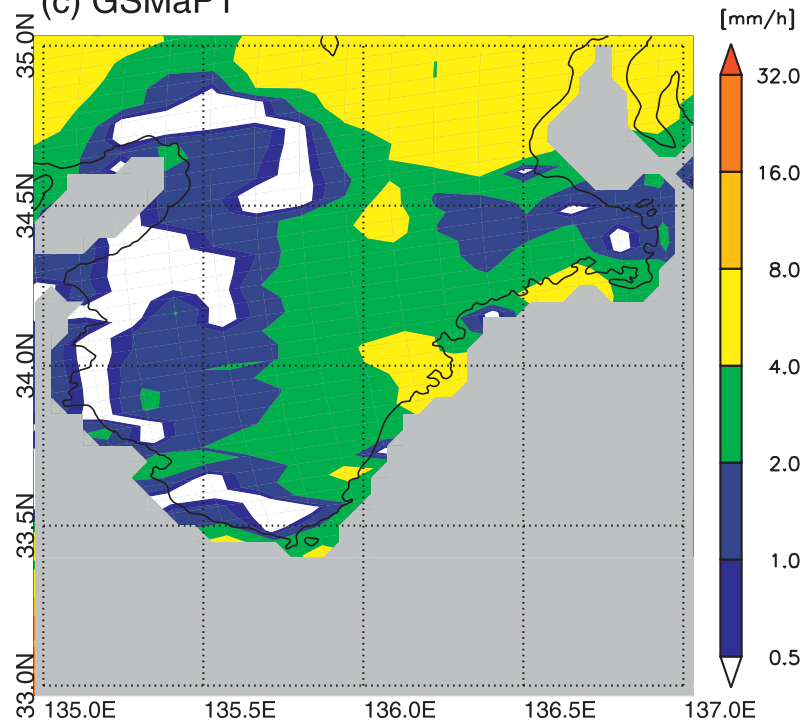

(b) TMI PCT85

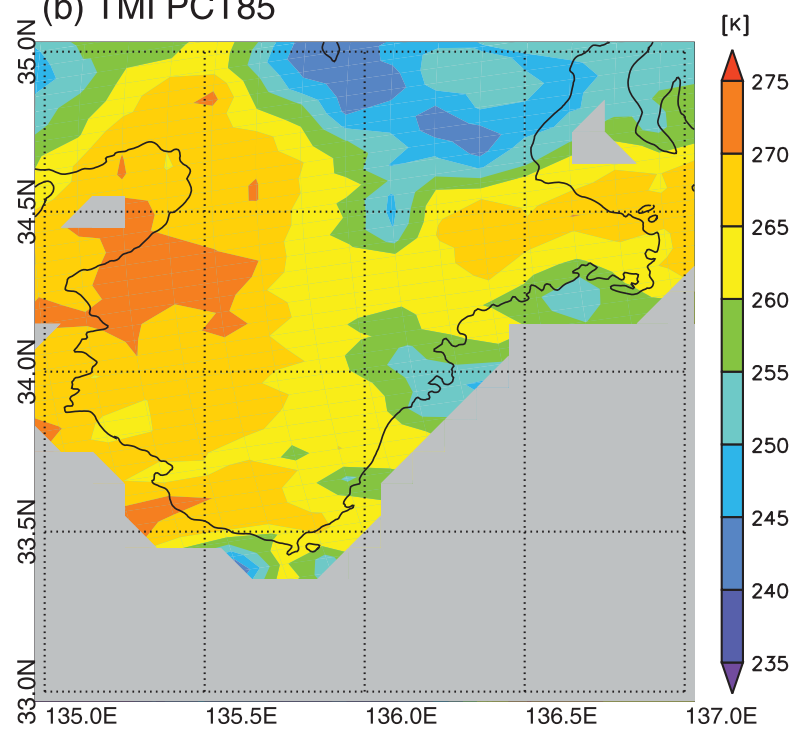

(d) GSMaP2

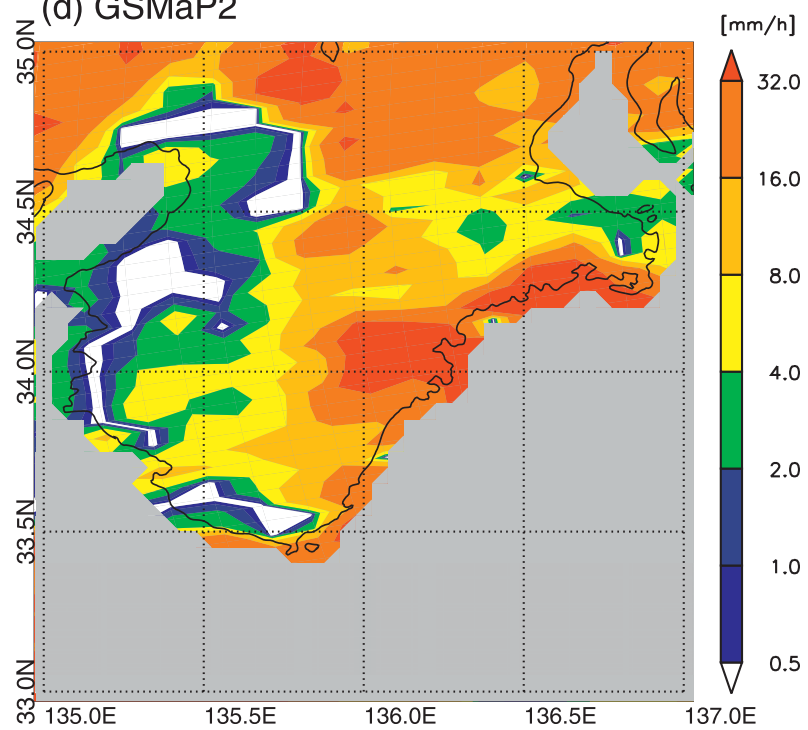

FIG. 4. Similar to Fig. 1, but for 30 Mar 2004 (TRMM orbit No. 36320): (a) PR 2A25 near-surface rain rate (mm h ${ }^{-1}$ ), (b) TMI PCT85 (K), (c) GSMaP1 surface rain $\left(\mathrm{mm} \mathrm{h}^{-1}\right)$, and (d) GSMaP2 surface rain $\left(\mathrm{mm} \mathrm{h}^{-1}\right)$. The observation times of PR and TMI data were 0550 and 0551 UTC, respectively.

GSMaP1 algorithm (Fig. 4c) from the TMI-observed PCT85 (Fig. 4b) are lower than PR estimates. The GPROF algorithm also underestimates surface rainfall (not shown). Figure 4d shows surface rainfall rates estimated by the GSMaP algorithm using the LUTs calculated from orographic precipitation profiles (hereinafter GSMaP2). The LUT calculated from orographic precipitation profiles provides better agreement between the GSMaP2 estimates and PR estimates along the southeast coast. The GSMaP2 estimates are greater than the PR estimates over all regions except the southeast coast, however.
The above results indicate the importance of separating precipitation profiles (and the LUTs derived from them) according to rain type (i.e., orographic or nonorographic rainfall) for radiometer rainfall estimates. This is a situation similar to that for radar rainfall estimates, in which separating raindrop size distributions (and radar reflectivity-rainfall rate relationships derived from them) according to rain type is important (Rosenfeld and Ulbrich 2003). In particular, for shallow orographic rainfall produced by low-level orographic lifting of maritime air (Fig. 5), raindrop size distributions have an extremely small median volume diameter in 


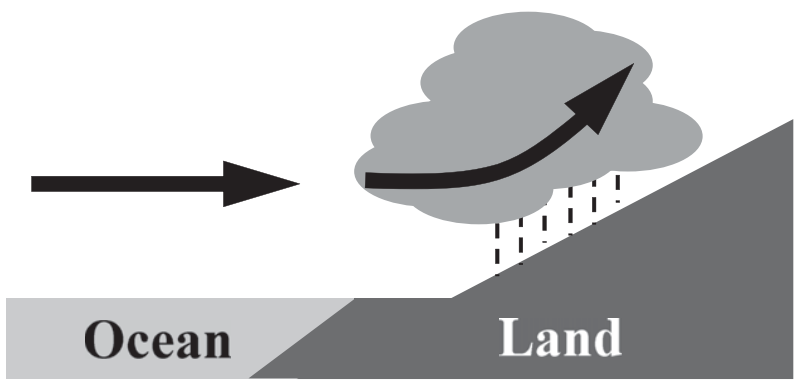

FIG. 5. Conceptual model of warm-rain processes enhanced by lowlevel orographic lifting of maritime air.

comparison with all other types. Hence, raindrop size distribution assumptions account for a gross radar underestimation of the orographic rainfall as well as nondetection of some shallow convection because of ground clutter. A larger number of small raindrops for orographic rainfall is attributed to active cloud-drop coalescence and warm-rain processes. The cloud-drop coalescence in maritime clouds with large cloud drops is so fast that rainfall develops low in the growing convective elements and precipitates while the clouds are still growing. This is consistent with the precipitation profiles without substantial upper-level ice particles shown in Figs. $2 \mathrm{c}$ and $2 \mathrm{~d}$. The area focused on in this study is a coastal region, and maritime air is thus orographically lifted.

Here, we develop an orographic/nonorographic rainfall classification scheme and dynamically select the LUTs that are calculated from orographic precipitation profiles or from original precipitation profiles (Fig. 6). As reviewed by Lin (2007) and Houze (2012), mechanisms by which mountains and hills affect precipitating clouds are extremely complicated and are highly dependent on many factors. In this study, only the case in which warm-rain processes are enhanced by low-level orographic lifting of maritime air (Fig. 5) is considered.

The orographically forced vertical motion may be roughly estimated from the lower boundary condition for flow over mountains (Lin 2007):

$$
w=\frac{D h}{D t}=\mathbf{V}_{H} \cdot \nabla h,
$$

where $h(x, y)$ is the terrain height as a function of $x$ and $y$ and $\mathbf{V}_{H}$ is the surface horizontal wind. Figure 7a shows the orographically forced vertical motion estimated from Eq. (1). Upward motion is found along the southeast coast where strong rainfall rates are estimated by the PR. Here, the horizontal wind in a $0.1^{\circ}$ cell is generated by spatially interpolating JRA data on a grid with $1.25^{\circ}$ resolution, and terrain height in a $0.1^{\circ}$ cell is

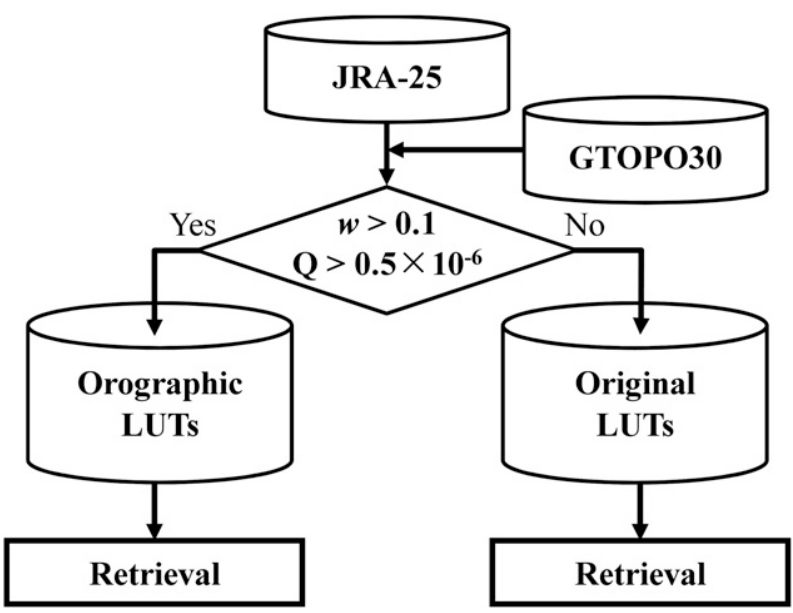

FIG. 6. Flowchart for GSMaP with an orographic/nonorographic rainfall classification scheme (GSMaP3).

generated by spatially smoothing U.S. Geological Survey global 30 arc-s elevation data (GTOPO30) with a horizontal grid spacing of approximately $1 \mathrm{~km}$.

The condition for the determination of an orographic rainfall pixel is

$$
w>0.1\left(\mathrm{~m} \mathrm{~s}^{-1}\right) .
$$

Besides the orographically forced vertical motion, the heavy orographic rainfall requires the convergence of surface moisture flux $Q$, and, therefore, the condition for the determination of an orographic rainfall pixel is given by

$$
Q>0.5 \times 10^{-6}\left(\mathrm{~s}^{-1}\right) .
$$

The 6-hourly JRA data with minimum time difference with the TRMM observations are employed for the conditions in Eqs. (2) and (3). On the other hand, the JRA data at 0000 UTC are used for LUTs that are calculated daily, because of computational costs. As shown in Fig. 6, for an orographic rainfall pixel determined by the conditions in Eqs. (2) and (3), the LUTs derived from orographic precipitation profiles (Figs. 2c,d) are used to estimate rainfall. On the other hand, for a nonorographic rainfall pixel, the LUTs derived from original precipitation profiles (Figs. 2a,b) are used to estimate rainfall. Hereinafter, the GSMaP algorithm that dynamically selects the LUTs according to orographic/nonorographic rainfall classification is referred to as GSMaP3.

Figures $7 \mathrm{~b}$ and $7 \mathrm{c}$ show the areas in which the orographic LUT was used by GSMaP3 and the GSMaP3 estimates, respectively. Dynamic selection of the LUTs on the basis of orographic/nonorographic rainfall classification gives good agreement between the GSMaP3 
(a) Upward vertical motion
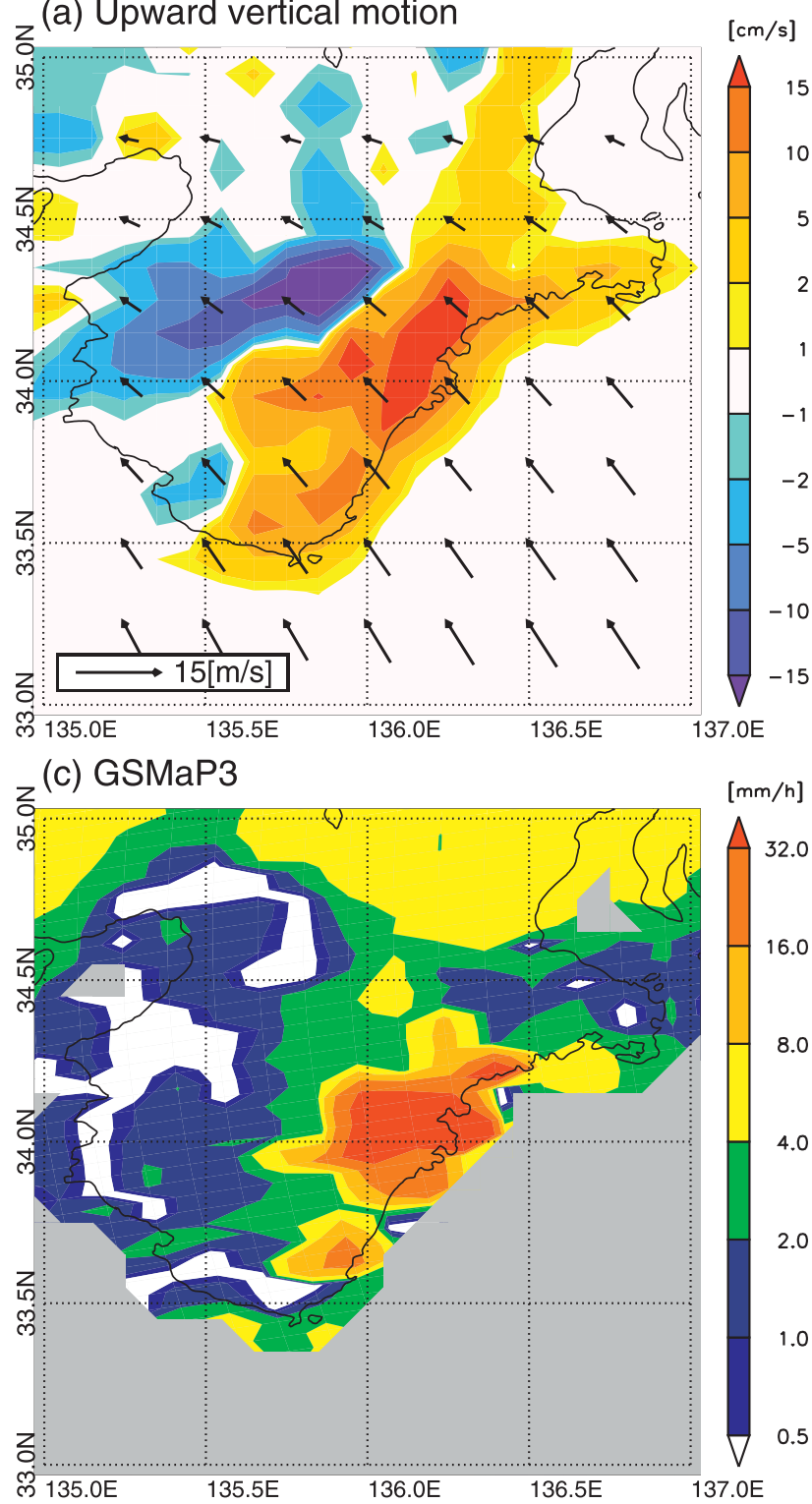

estimates and PR estimates over all regions. The areas determined by the condition in Eq. (2) are included in those determined by the condition in Eq. (3). Therefore, the areas in which the orographic LUT was used by GSMaP3 (Fig. 7b) correspond to those determined by Eq. (2). A threshold in Eq. (2) can be selected liberally (i.e., detection of the areas with weak upward motion at the expense of misclassifying nonorographic rain pixels) or conservatively (i.e., detection of only upward motion above a certain threshold at the expense of eliminating some orographic rain pixels). This is a situation similar to that for rain/no-rain classification methods for MWR observations (Ferraro et al. 1998). The threshold in (b) orographic LUT areas

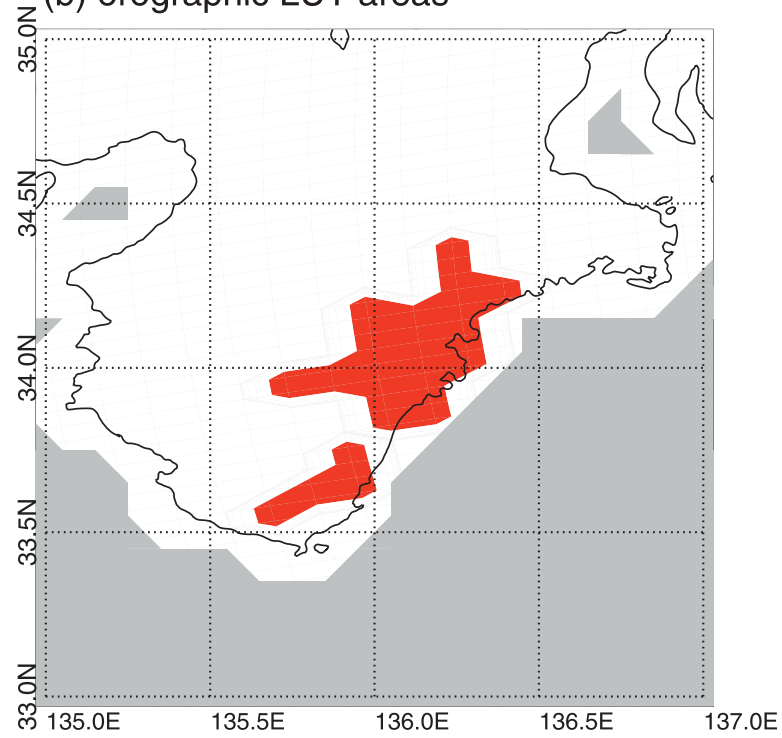

FIG. 7. As in Fig. 4, but for (a) orographically forced vertical motion ( $\mathrm{cm} \mathrm{s}^{-1}$ ) estimated using Eq. (1) with surface horizontal winds from JRA data at 0600 UTC 30 Mar 2004, (b) the areas in which the orographic LUT was used by GSMaP3, and (c) GSMaP3 surface rain $\left(\mathrm{mm} \mathrm{h}^{-1}\right)$.
Eq. (2) seems to be conservative for the case shown in Fig. 7 and should be parameterized as is done for rain/norain threshold values of the cloud liquid water path (Kida et al. 2009, 2010), but this is left for future studies. The role of the condition in Eq. (3) will be described in section $3 \mathrm{~b}$.

\section{b. Comparisons with the RA}

Figure 8 a depicts the RA rain rates averaged during summer (June-August 2004) over the Kii Peninsula when the swath of the TMI passes. The GSMaP1 algorithm did poorly in estimating the rain maximum over the Kii Peninsula (Fig. 8c). Large negative values below $500 \mathrm{~mm} \mathrm{month}{ }^{-1}$ found in areas with heavy orographic 
VOLUME 52

(a) RA (summer)
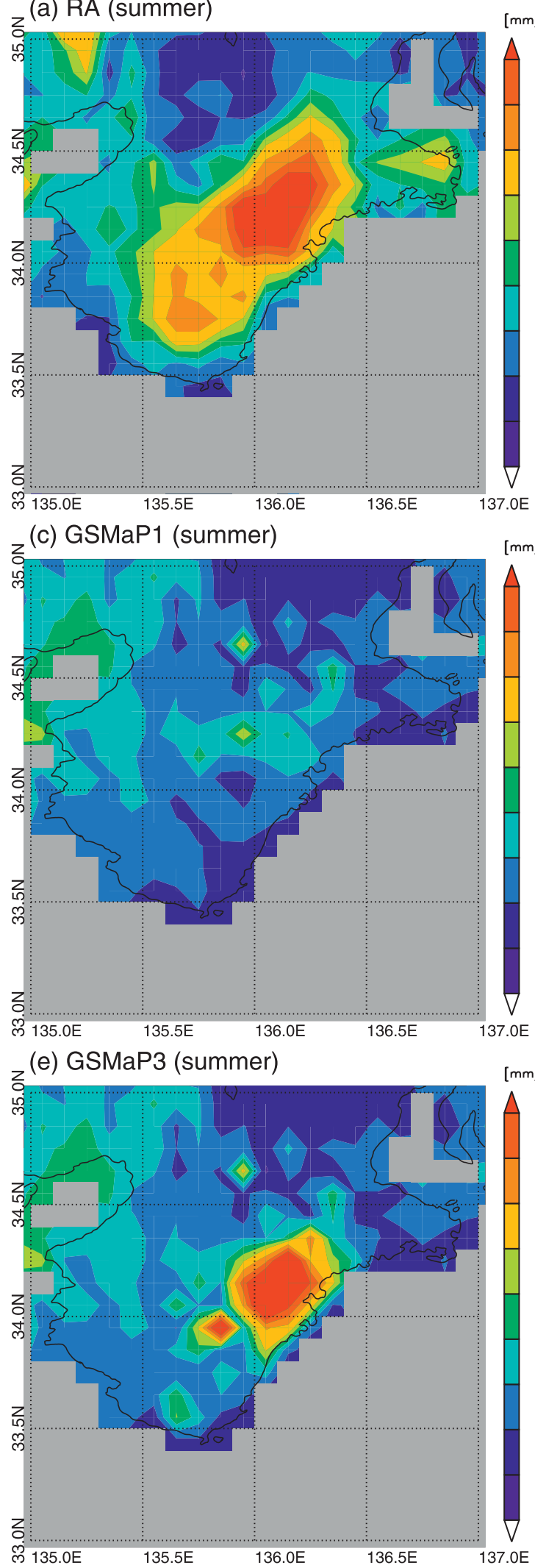

(b) RA (winter)

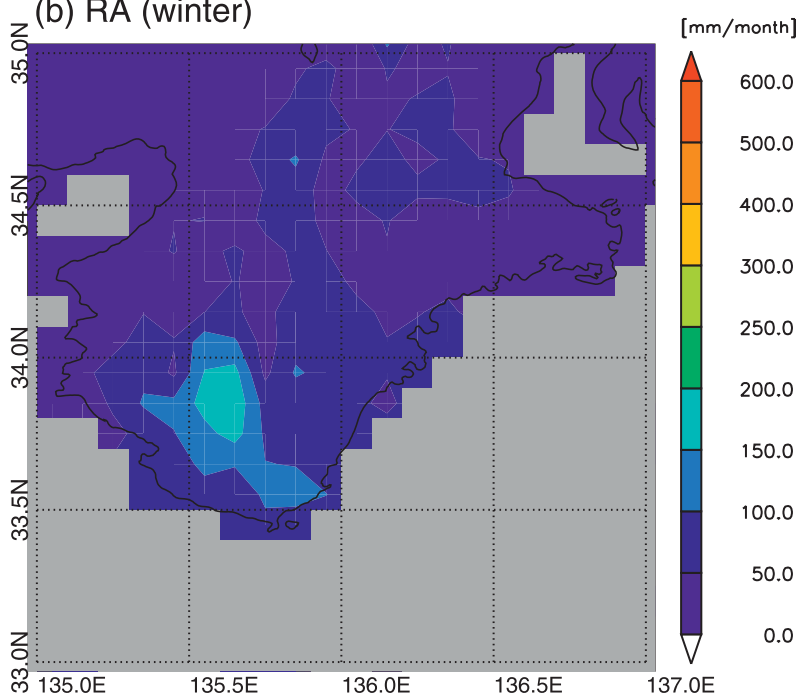

(d) GSMaP1 (winter)

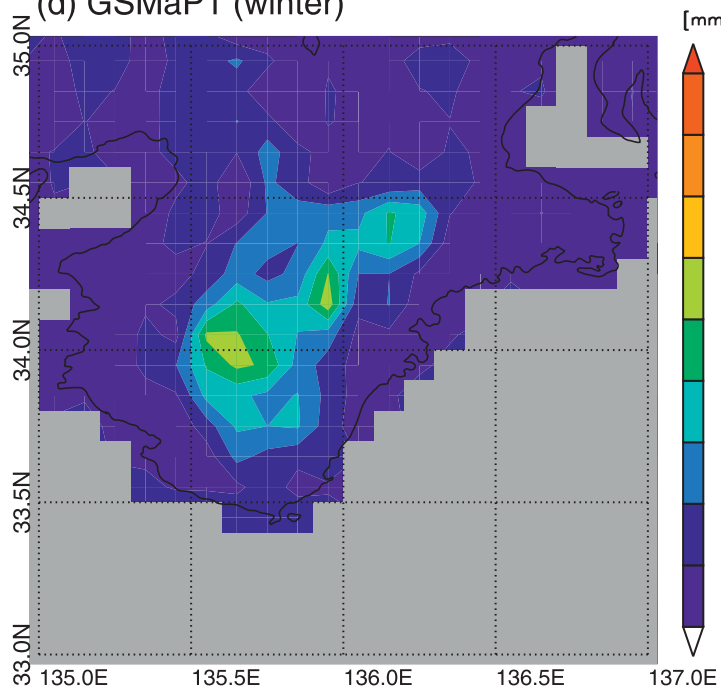

$\mathrm{mm} / \mathrm{month}$ ]

600.0

500.0

400.0

300.0

250.0

200.0

150.0

100.0

50.0

0.0

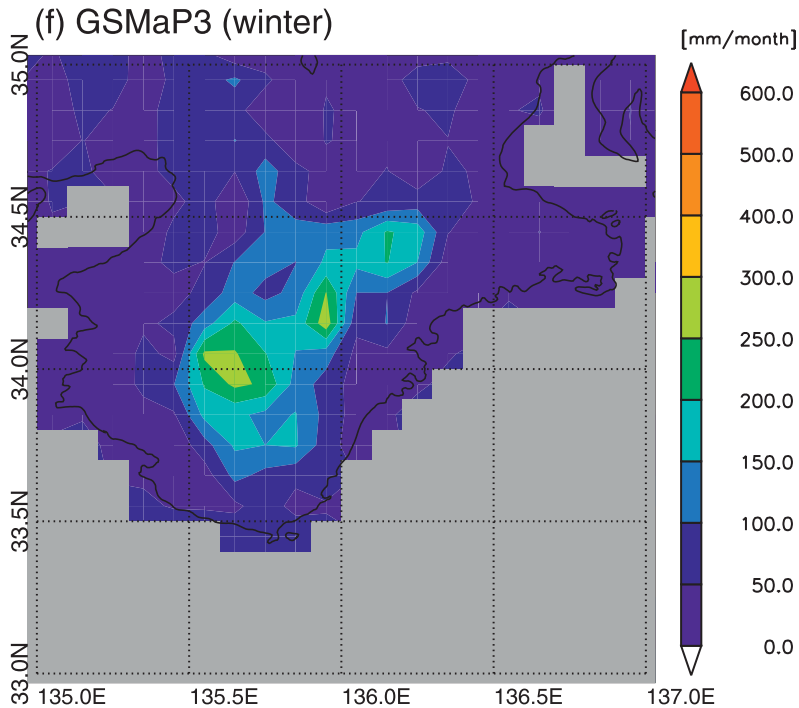

FIG. 8. Averages rain rates for (left) summer (June-August 2004) and (right) winter (January, February, and December 2004) for (a),(b) RA, (c),(d) GSMaP1, and (e),(f) GSMaP3. 
(a) GSMaP1 - RA (summer)

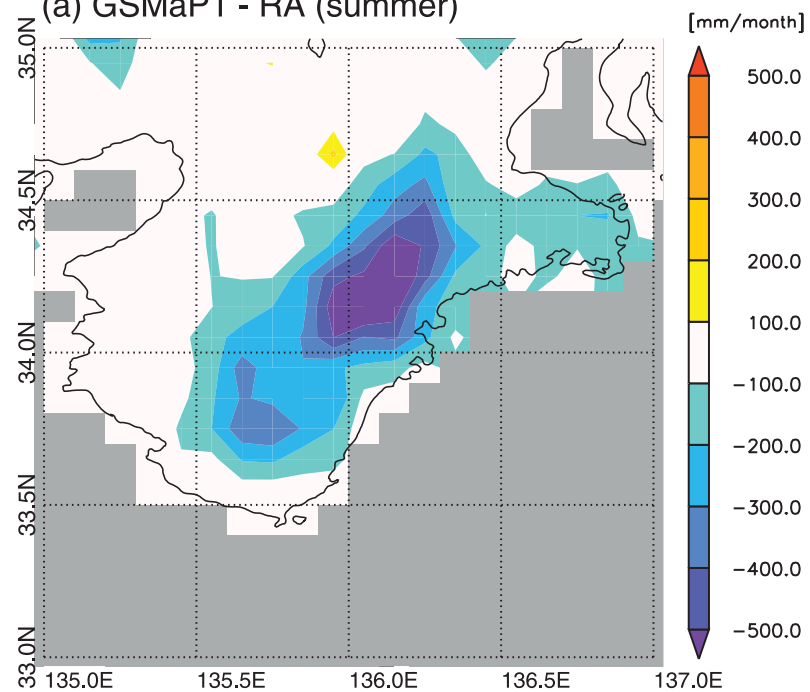

(c) GSMaP3 - RA (summer)

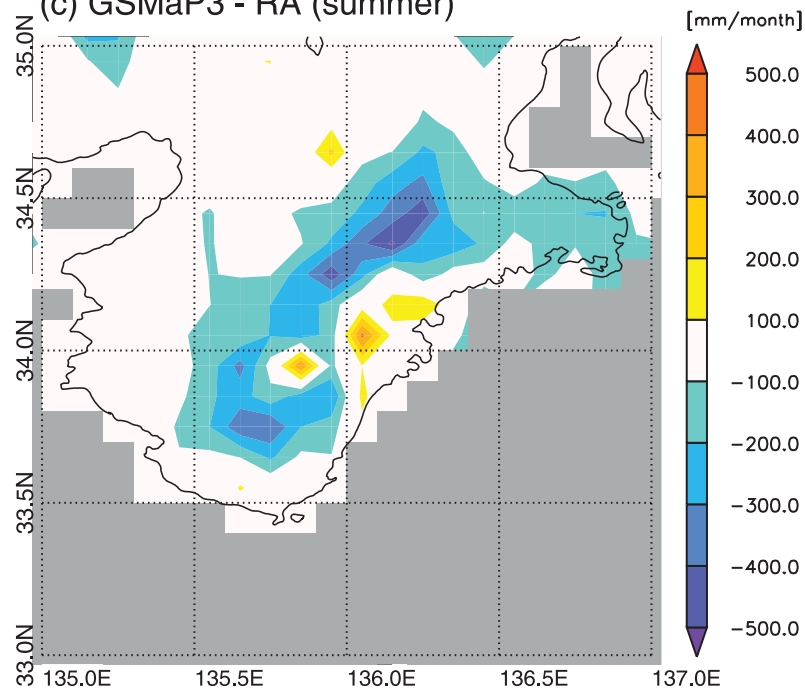

(b) GSMaP1 - RA (winter)

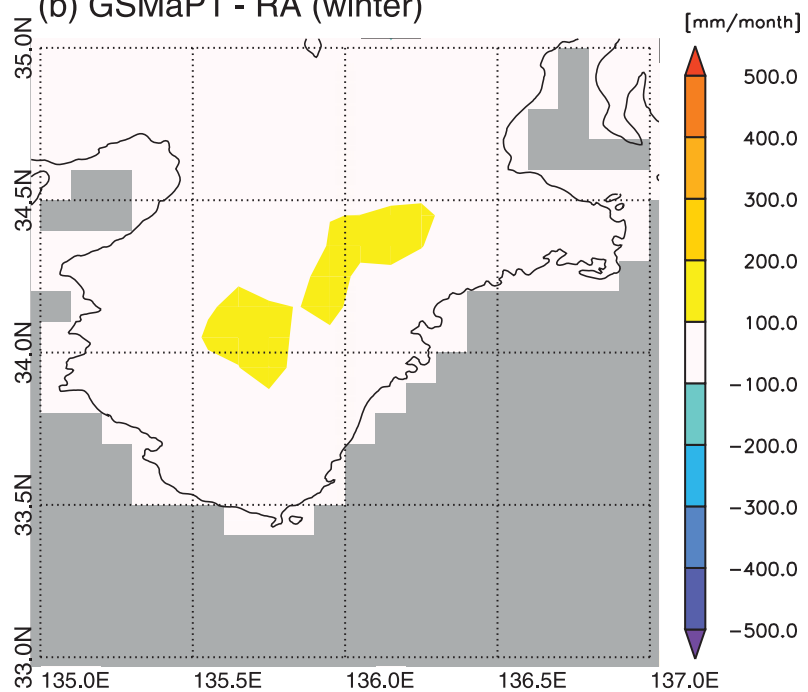

(d) GSMaP3 - RA (winter)

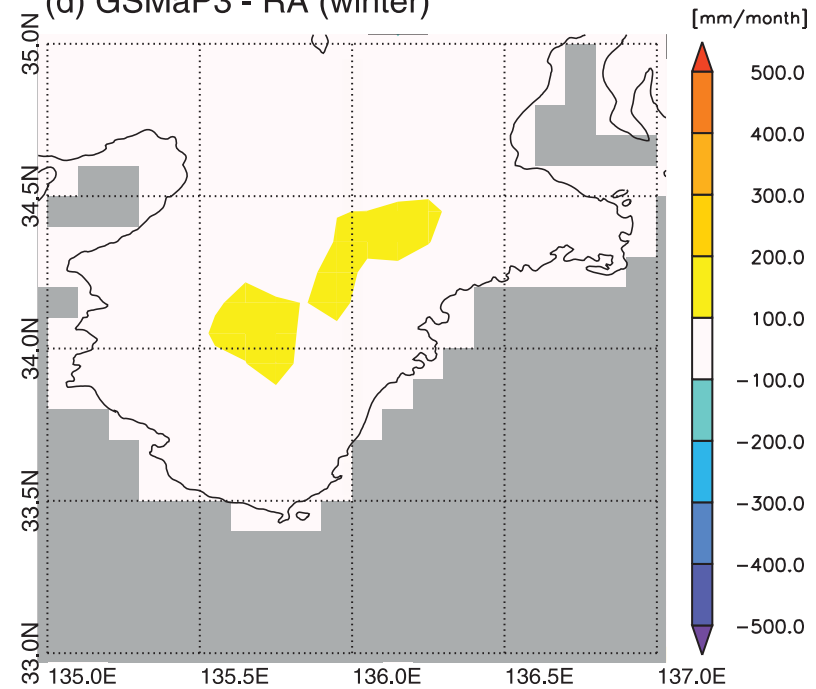

FIG. 9. Rain-rate differences (a),(b) between GSMaP1 and RA (i.e., GSMaP1 - RA) and (c),(d) between GSMaP3 and RA (i.e., GSMaP3 - RA) for (left) summer (June-August 2004) and (right) winter (January, February, and December 2004).

rainfall (Fig. 9a) indicate underestimation of the GSMaP1 there. This result is consistent with those reported by Negri and Adler (1993) and Kubota et al. (2009). On the other hand, the rain maximum can be seen in the GSMaP3 rain rates (Fig. 8e). Underestimation by the GSMaP1 algorithm for summer is mitigated by orographic/ nonorographic rainfall classification in the GSMaP3 algorithm, especially in coastal regions. Although there are still negative values in Fig. 9c, the GSMaP3 estimates are in better agreement with the RA estimates than are the GSMaP1 estimates. As discussed earlier, the threshold in Eq. (2) seems to be conservative and orographic/ nonorographic rainfall classification may involve incorrectly eliminating some orographic rain pixels.
The RA rain rates averaged during winter (January, February, and December 2004) shown in Fig. 8b are much lower than those during summer shown in Fig. 8a. Correspondingly, differences between GSMaP1 and RA for winter (Fig. 9b) are much smaller than those for summer (Fig. 9a). In contrast to the results for summer, the GSMaP3 rain rates (Fig. 8f) and differences between GSMaP3 and RA (Fig. 9d) for winter are the same as those for GSMaP1 (Figs. 8d, 9b). The results suggest that orographic LUTs are used in summer but not in winter.

To clarify why orographic LUTs are not used in winter, rain is estimated by the GSMaP algorithm using a modified orographic/nonorographic rainfall classification in which an orographic rainfall pixel is determined only by 
(a) GSMaP4 - RA (summer)

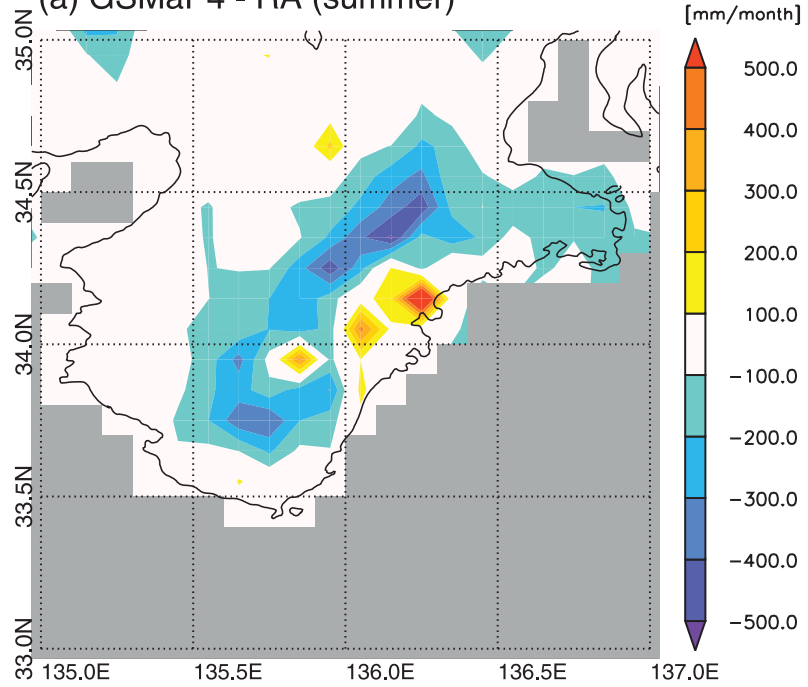

(b) GSMaP4 - RA (winter)

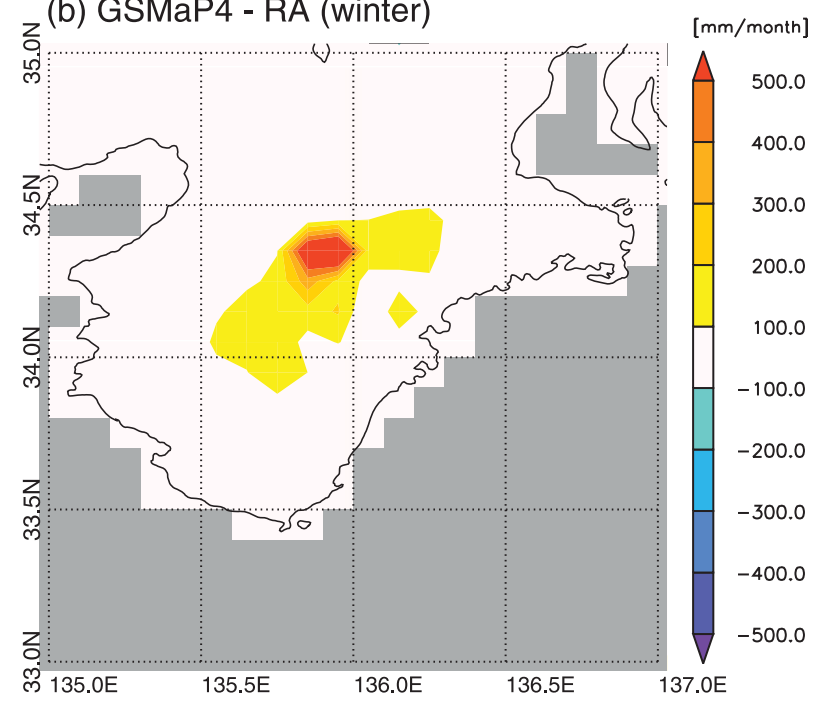

FIG. 10. As in Fig. 9, but for differences between GSMaP4 and RA (i.e., GSMaP4 - RA).

the condition in Eq. (2), which procedure is referred to as GSMaP4. For summer, differences between GSMaP4 and RA (Fig. 10a) are almost the same as those between GSMaP3 and RA (Fig. 9c) except at some locations with large positive values. In contrast, for winter, overestimation in GSMaP1 and GSMaP3 is exaggerated by orographic/nonorographic rainfall classification in GSMaP4 (Fig. 10b). Therefore, because of the condition in Eq. (3), orographic rain is not detected by the orographic/nonorographic rainfall classification during winter. This is consistent with the fact that heavy rainfall associated with shallow orographic rain systems is observed in summer (Takeda et al. 1976; Takeda and Takase 1980; Sakakibara 1981).

\section{Summary and conclusions}

In this paper, we improved the performance of rainfall estimates made by the GSMaP algorithm (Aonashi et al. 2009; Kubota et al. 2007) from the TMI data over the Kii Peninsula, which is a heavy-rainfall region in Japan for which satellite methods have been shown in previous studies to poorly estimate the rain maximum (Negri and Adler 1993; Kubota et al. 2009). We developed an orographic/ nonorographic rainfall classification scheme that is based on orographically forced upward vertical motion and the convergence of surface moisture flux, and we dynamically selected LUTs that are calculated from orographic precipitation profiles or from original precipitation profiles. Rainfall estimates made by the revised GSMaP algorithm are in much better agreement with PR and RA estimates than are those made by the original GSMaP algorithm.

Some of the rainiest areas of the world, such as the west coast of India during the summer monsoon, are dominated by shallow orographic rain systems (Houze 1993; Liu and Zipser 2009). The orographic/nonorographic rainfall classification scheme has the potential to significantly improve radiometer rainfall estimates over these areas. For the global application of the revised algorithm, however, it is necessary to examine mechanisms by which mountains and hills affect precipitating clouds and thus shape precipitation profiles. As reviewed by Lin (2007) and Houze (2012), the mechanisms are extremely complicated. In this study, only the simplest mechanism, enhancement by orographically forced upward vertical motion, is considered. Even this low-level orographic enhancement depends on the cloud microstructure and is complicated. Rosenfeld and Ulbrich (2003) suggested that the low-level enhancement would probably be weaker in more microphysically continental clouds with small cloud drops than in more microphysically maritime clouds with large cloud drops. Therefore, precipitation profiles would probably have more upperlevel ice particles in more microphysically continental clouds than in more microphysically maritime clouds.

Numerical assimilation and forecast systems are continuously improving, leading to better reanalyses. Hodges et al. (2011) showed that differences in extratropical cyclones are largest between the older lower-resolution JRA-25 and the newer high-resolution reanalyses, particularly in the Southern Hemisphere. Comparisons of orographic and nonorographic rainfall classification schemes using reanalyses are interesting but are left to future studies.

Acknowledgments. The authors thank Prof. C. Kummerow from Colorado State University for a suggestion at the initial stage of this study. This study is supported 
by the Earth Observation Research Center, the Japan Aerospace Exploration Agency, a Grant-in-Aid for Scientific Research (KAKENHI), and the Environment Fund of Mitsui \& Co., Ltd. The authors thank three anonymous reviewers for their constructive comments that improved the clarity of the paper.

\section{REFERENCES}

Adler, R. F., A. J. Negri, P. R. Keehn, and I. M. Hakkarinen, 1993: Estimation of monthly rainfall over Japan and surrounding waters from a combination of low-orbit microwave and geosynchronous IR data. J. Appl. Meteor., 32, 335-356.

Aonashi, K., and Coauthors, 2009: GSMaP passive microwave precipitation retrieval algorithm: Algorithm description and validation. J. Meteor. Soc. Japan, 87A, 119-136.

Ferraro, R. R., E. A. Smith, W. Berg, and G. J. Huffman, 1998: A screening methodology for passive microwave precipitation retrieval algorithms. J. Atmos. Sci., 55, 1583-1600.

Gebrenuchael, M., and F. Hossain, Eds., 2010: Satellite Rainfall Applications for Surface Hydrology. Springer, 327 pp.

Hodges, K. I., R. W. Lee, and L. Bengtsson, 2011: A comparison of extratropical cyclones in recent reanalyses ERA-Interim, NASA MERRA, NCEP CFSR, and JRA-25. J. Climate, 24, 4888-4906.

Hong, Y., R. F. Alder, A. Negri, and G. J. Huffman, 2007: Flood and landslide applications of near real-time satellite rainfall products. Nat. Hazards, 43, 285-294.

Houze, R. A., Jr., 1993: Cloud Dynamics. Academic Press, 573 pp. , 2012: Orographic effects on precipitating clouds. Rev. Geophys., 50, RG1001, doi:10.1029/2011RG000365.

Huffman, G. J., and Coauthors, 2007: The TRMM Multisatellite Precipitation Analysis (TMPA): Quasi-global, multi-year, combined-sensor precipitation estimates at fine scale. J. Hydrometeor., 8, 38-55.

Iguchi, T., T. Kozu, R. Meneghini, J. Awaka, and K. Okamoto, 2000: Rain-profiling algorithm for the TRMM precipitation radar. J. Appl. Meteor., 39, 2038-2052.

- - - J. Kwiatkowski, R. Meneghini, J. Awaka, and K. Okamoto, 2009: Uncertainties in the rain profiling algorithm for the TRMM precipitation radar. J. Meteor. Soc. Japan, 87A, 1-30.

Joyce, R. J., J. E. Janowiak, P. A. Arkin, and P. Xie, 2004: CMORPH: A method that produces global precipitation estimates from passive microwave and infrared data at high spatial and temporal resolution. J. Hydrometeor., 5, 487-503.

Kida, S., S. Shige, T. Kubota, K. Aonashi, and K. Okamoto, 2009: Improvement of rain/no-rain classification methods for microwave radiometer observations over ocean using the $37-\mathrm{GHz}$ emission signature. J. Meteor. Soc. Japan, 87A, 165-181.

$\longrightarrow,-$, T. Manabe, T. S. L'Ecuyer, and G. Liu, 2010: Cloud liquid water path for the rain/no-rain classification method over ocean in the GSMaP algorithm. Trans. Japanese Soc. Artif. Intell. Aerosp. Tech. Japan, 8, 19-23.

Kidd, C. K., D. R. Kniveton, M. C. Todd, and T. J. Bellerby, 2003 Satellite rainfall estimation using combined passive microwave and infrared algorithms. J. Hydrometeor., 4, 1088-1104.

_ - R. Ferraro, and V. Levizzani, 2010: The fourth International Precipitation Working Group workshop. Bull. Amer. Meteor. Soc., 91, 1095-1099.

Kozu, T., and Coauthors, 2001: Development of precipitation radar onboard the Tropical Rainfall Measuring Mission (TRMM) satellite. IEEE Trans. Geosci. Remote Sens., 39, 102-116.
Kubota, T., and Coauthors, 2007: Global precipitation map using satelliteborne microwave radiometers by the GSMaP project: Production and validation. IEEE Trans. Geosci. Remote Sens., 45, 2259-2275.

, T. Ushio, S. Shige, S. Kida, M. Kachi, and K. Okamoto, 2009: Verification of high resolution satellite-based rainfall estimates around Japan using gauge-calibrated ground radar dataset. J. Meteor. Soc. Japan, 87A, 203-222.

Kuligowski, R. J., 2002: A self-calibrating real-time GOES rainfall algorithm for short-term rainfall estimates. J. Hydrometeor., 3, $112-130$

Kummerow, C., and Coauthors, 2001: The evolution of the Goddard profiling algorithm (GPROF) for rainfall estimation from passive microwave sensors. J. Appl. Meteor., 40, 18011820.

Kwon, E.-H., B.-J. Sohn, D.-E. Chang, M.-H. Ahn, and S. Yang, 2008: Use of numerical forecasts for improving TMI rain retrievals over the mountainous area in Korea. J. Appl. Meteor. Climatol., 47, 1995-2007.

Lin, Y.-L., 2007: Mesoscale Dynamics. Cambridge, 630 pp.

Liu, C., and E. J. Zipser, 2009: "Warm rain" in the tropics: Seasonal and regional distribution based on $9 \mathrm{yr}$ of TRMM data. J. Climate, 22, 767-779.

Liu, G., 1998: A fast and accurate model for microwave radiance calculations. J. Meteor. Soc. Japan, 76, 335-343.

Makihara, Y., 2007: Steps towards decreasing heavy rain disasters by short-range precipitation and land-slide forecast using weather radar accompanied by improvement of meteorological operational activities (in Japanese). Tenki, 54, 21-33.

_ N. Uekiyo, A. Tabata, and Y. Abe, 1996: Accuracy of RadarAMeDAS precipitation. IEICE Trans. Commun., 79, 751-762.

McCollum, J. R., and R. R. Ferraro, 2003: Next generation of NOAA/NESDIS TMI, SSM/I, and AMSR-E microwave land rainfall algorithms. J. Geophys. Res., 108, 8282, doi:10.1029/ 2001JD001512.

$\longrightarrow$, and - 2005: Microwave rainfall estimation over coasts. J. Atmos. Oceanic Technol., 22, 497-512.

Negri, A. J., and R. F. Adler, 1993: An intercomparison of three satellite infrared rainfall techniques over Japan and surrounding waters. J. Appl. Meteor., 32, 357-373.

Okamoto, K., 2003: A short history of the TRMM precipitation radar. Cloud Systems, Hurricanes and the Tropical Rainfall Measurement Mission (TRMM): A Tribute to Dr. Joanne Simpson, Meteor. Monogr., No. 51, Amer. Meteor. Soc., 187195.

Olson, W. S., and Coauthors, 2006: Precipitation and latent heating distributions from satellite passive microwave radiometry. Part I: Improved method and uncertainties. J. Appl. Meteor. Climatol., 45, 702-720.

Onogi, K., and Coauthors, 2007: The JRA-25 Reanalysis. J. Meteor. Soc. Japan, 85, 369-432.

Rosenfeld, D., and C. W. Ulbrich, 2003: Cloud microphysical properties, process, and rainfall estimation opportunities. Radar and Atmospheric Science: A Collection of Essays in Honor of David Atlas, Meteor. Monogr., No. 52, Amer. Meteor. Soc., 237-258.

Sakakibara, H., 1981: Heavy rainfall from very shallow convective clouds. J. Meteor. Soc. Japan, 59, 387-394.

Scofield, R. A., and R. J. Kuligowski, 2003: Status and outlook of operational satellite precipitation algorithms for extremeprecipitation events. Wea. Forecasting, 18, 1037-1051.

Seto, S., N. Takahashi, and T. Iguchi, 2005: Rain/no-rain classification methods for microwave radiometer observations over 
land using statistical information for brightness temperatures under no-rain conditions. J. Appl. Meteor., 44, 1243-1259.

Shige, S., T. Watanabe, H. Sasaki, T. Kubota, S. Kida, and K. Okamoto, 2008: Validation of western and eastern Pacific rainfall estimates from the TRMM PR using a radiative transfer model. J. Geophys. Res., 113, D15116, doi:10.1029/ 2007JD009002.

Simpson, J., C. Kummerow, W.-K. Tao, and R. F. Adler, 1996: On the Tropical Rainfall Measuring Mission (TRMM). Meteor. Atmos. Phys., 60, 19-36.

Sorooshian, S., K.-L. Hsu, X. Gao, H. V. Gupta, B. Imam, and D. Braithwaite, 2000: Evaluation of PERSIANN system satellite-based estimates of tropical rainfall. Bull. Amer. Meteor. Soc., 81, 2035-2046.

Spencer, R. W., H. M. Goodman, and R. E. Hood, 1989: Precipitation retrieval over land and ocean with SSM/I: Identification and characteristics of the scattering signal. J. Atmos. Oceanic Technol., 6, 254-273.

Takayabu, Y. N., 2006: Rain-yield per flash calculated from TRMM PR and LIS data and its relationship to the contribution of tall convective rain. Geophys. Res. Lett., 33, L18705, doi:10.1029/2006GL027531.

, 2008: Observing rainfall regimes using TRMM PR and LIS data. GEWEX News, 18, 9-10.
Takeda, T., and K. Takase, 1980: Radar observation of rainfall system modified by orographic effects. J. Meteor. Soc. Japan, $\mathbf{5 8}, 500-516$.

— N. Moriyama, and Y. Iwasaka, 1976: A case study of heavy rain in Owase area. J. Meteor. Soc. Japan, 54, 32-41.

Todd, M. C., and J. O. Bailey, 1995: Estimates of rainfall over the United Kingdom and surrounding seas from the SSM/I using the polarization corrected temperature algorithm. J. Appl. Meteor., 34, 1254-1265.

Turk, F. J., and S. D. Miller, 2005: Toward improving estimates of remotely sensed precipitation with MODIS/AMSR-E blended data techniques. IEEE Trans. Geosci. Remote Sens., 43, 1059-1069.

Ushio, T., and Coauthors, 2009: A Kalman filter approach to the global satellite mapping of precipitation (GSMaP) from combined passive microwave and infrared radiometric data. J. Meteor. Soc. Japan, 87A, 137-151.

Vicente, G. A., J. C. Davenport, and R. A. Scofield, 2002: The role of orographic and parallax corrections on real time high resolution satellite rainfall estimation. Int. J. Remote Sens., 23, 221-230.

Wang, N.-Y., C. Liu, R. Ferraro, D. Wolff, E. Zipser, and C. Kummerow, 2009: TRMM 2A12 land precipitation productStatus and future plans. J. Meteor. Soc. Japan, 87A, 237-253. 